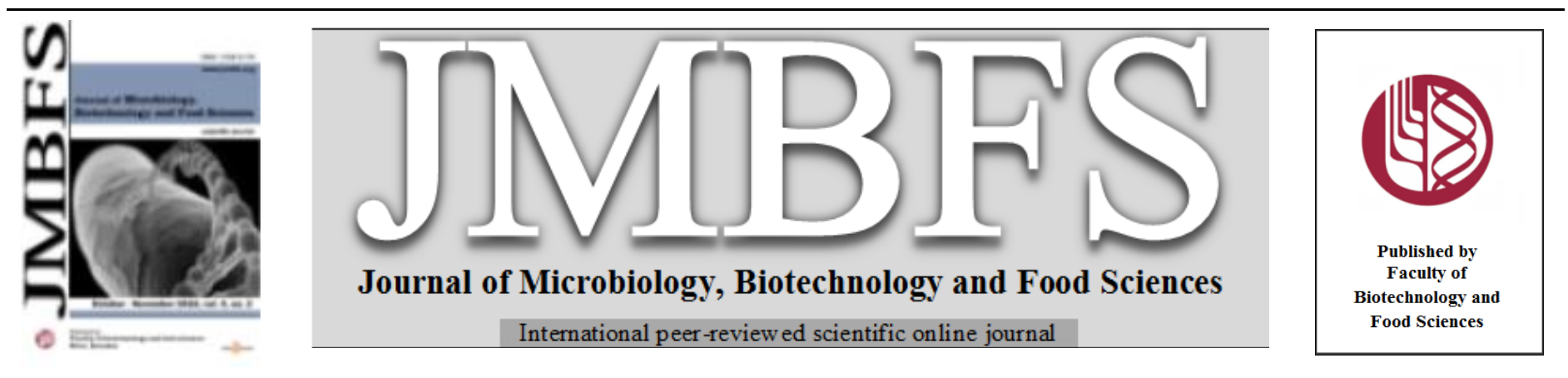

\title{
MICROBIAL LIPASES - PROPERTIES AND APPLICATIONS
}

\section{Prakasan Priji, Sreedharan Sajith, Panichikkal Abdul Faisal, Sailas Benjamin*}

Address(es):

Enzyme Technology Laboratory, Biotechnology Division, Department of Botany, University of Calicut, Kerala - 673635, India.

*Corresponding author: benjamin@uoc.ac.in

doi: 10.15414/jmbfs.2016.6.2.799-807

\section{ARTICLE INFO}

Received 16. 3. 2015

Revised 18. 5. 2016

Accepted 12.7. 2016

Published 3. 10. 2016

Review

\begin{abstract}
Owing to wide spectrum of catalytic reactions both in aqueous and non-aqueous media, microbial lipases occupy an unquestionable position among the biocatalysts. The chemo-, regio- and enantio-specificities of lipases have contributed to their versatile applications in biotechnology. As far as global scenario is concerned, microbial lipases - especially from bacteria and fungi - contribute to the choice of interest to meet the commercial needs. At this context, this review critically looks into the major domains of microbial lipases with an industrial perspective, which include: properties, secretion and industrial applications with appropriate illustrations. Due to great specificity and versatility of the reactions catalyzed, lipases claim unique applications in various process and products industries engaged in food, dairy, fats and oils, detergency, tannery, pharmaceutics and cosmetics.
\end{abstract}

Keywords: Hydrolysis, trans-esterification, interfacial activation, active site, applications

\section{INTRODUCTION}

Enzymes are considered as the biocatalysts of nature. The increasing concerns about the environmental pollutions and stringent government regulations over the world have turned the attention of industries toward green technologies. Majority of the industrial enzymes are of microbial origin. Until the 1960s, the total sale of enzymes was only a few million dollars annually; since then, the market was broadened up spectacularly. At present, more than 200 microbial enzymes are used commercially and approximately 20 types are produced on truly industrial scale (Li et al. 2012; Pandey et al. 1999). Most of the enzymes produced by the industry are hydrolytic in nature; of which lipolytic enzymes draw enormous attention, because of their immense biotechnological potentials. Lipids constitute an abundant biomass on earth, and lipolytic enzymes play the pivotal role in the conversion of these hydrophobic compounds to simpler units (Benjamin \& Pandey 1998).

Lipases or triacylglycerol hydrolases (E.C. 3.1.1.3) are ubiquitous enzymes mediating the hydrolysis and synthesis of esters formed by the conjugation of glycerol and long-chain fatty acids (Hasan et al. 2006). Physiologically lipase hydrolyzes triglycerides into diglycerides, monoglycerides, fatty acids and glycerol. They are abundant in animals, plants, bacteria and fungi; where they play the crucial role in lipid metabolism. For the past few decades, lipases have gained much attention due to their versatile activities toward extreme temperature, $\mathrm{pH}$, organic solvents; and chemo-, regio- and enantio-selectivities (Benjamin \& Pandey 1996). In contrast to esterases, lipases are activated only when adsorbed to an oil-water interface i.e., lipase possesses a unique property of catalyzing the hydrolysis of ester bonds at the interface between an insoluble substrate phase and the aqueous phase, where the enzyme remains dissolved (Benjamin \& Pandey 2000; Priji et al. 2014). For the past two decades, the world-wide production and consumption of microbial lipases have increased considerably owing to their fascinating industrial applications, which summarize the lipases as the third largest group of enzymes after proteases and amylases. In fact, the panorama of lipase utilization encompasses many industries like dairy, food, detergents, textile, pharmaceutical, cosmetic, biodiesel, etc. (Schmid \& Verger 1998)

Upon this background, this review examines the advancements in the various domains of microbial lipases such as production, properties, secretion and industrial applications.

\section{MICROBIAL SOURCES OF LIPASES}

Lipases are produced by several microorganisms, namely bacteria, fungi, archea, eucarya; as well as animals and plants - among which bacteria, fungi and yeasts yield the majority of commercial lipases. The commercial significance of microbial lipases is mainly attributed to their vast variety of catalytic activities, ease of genetic manipulation and high yield, coupled with exponential growth of the producing microbes in inexpensive media and absence of seasonal fluctuations (Benjamin \& Pandey 1996). Moreover, most of the microbial lipases do not require cofactors for their activation, and they exhibit broad range of substrate specificity and high enantioselectivity (Kirk et al. 2002). Many species of bacteria such as Pseudomonas, Bacillus, Serratia, Alcaligens, etc., fungi such as Aspergillus, Penicillium, and yeast Candida, etc. are known to produce lipases (Table 1). The potential for the production of lipases enable these microbes to utilize the non-conventional carbon sources such as lipids that cannot directly pass through the cell membrane and have to hydrolyze partially to release free fatty acids prior to the cellular uptake (Najjar et al. 2011). Even though, a vast variety of microbial species are known for lipase production, only a few are utilized commercially and most of them are extracellular inducible enzymes. i.e they are synthesized within the cell in the presence of inducers of long chain fatty acids such as vegetable oils, oil industry wastes, surfactants, triglycerides, etc. and are secreted to the external environment. 
Table 1 Some bacteria and fungi producing lipase, their sources of isolation, and yield of lipase using different inducers

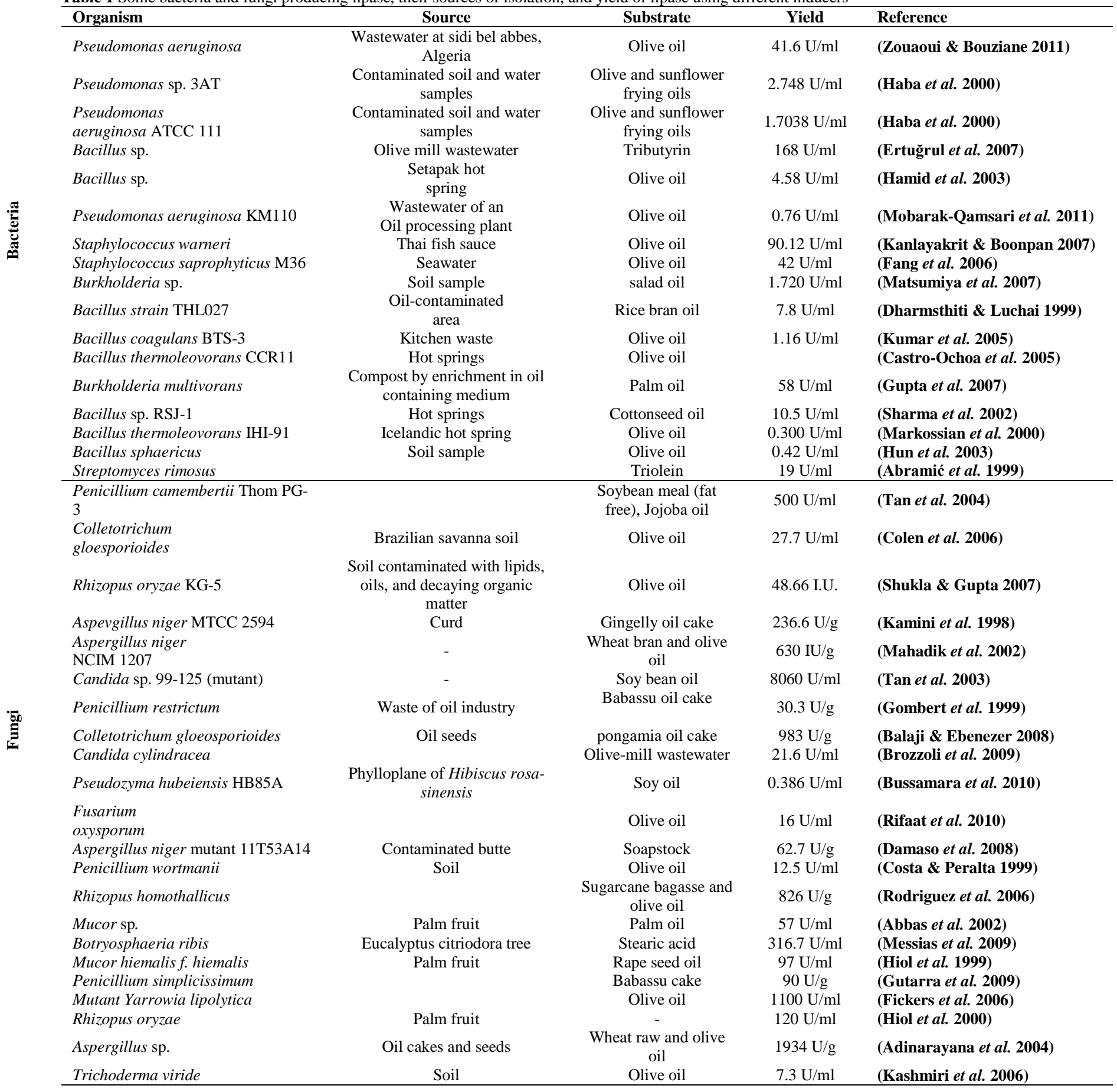

\section{REACTIONS CATALYZED BY LIPASE}

Lipases catalyze a variety of reactions, which are primarily determined by the availability of water. Principally, they catalyze the hydrolysis of triglycerides at the aqueous-non aqueous interface, and favour the synthesis of esters from alcohols and long chain fatty acids when the water activity is low (Aravindan $\boldsymbol{e t}$ al. 2007), i.e, lipases can catalyze esterification, inter-esterification, and transesterification reactions in non-aqueous environments (Table 2). Thus, the versatility in activities makes lipases a suitable choice of catalyst in many industries. 
Table 2 The reactions catalyzed by lipase

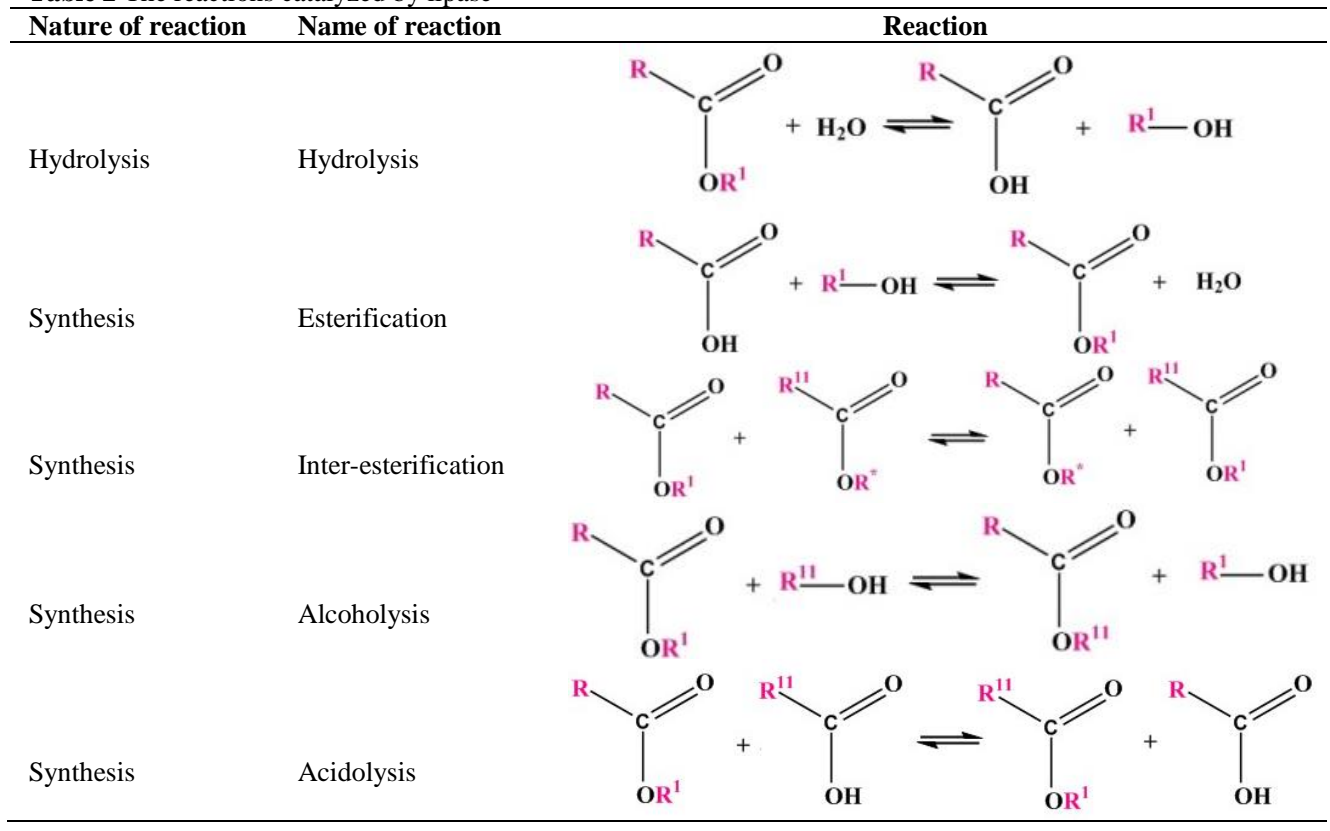

\section{PROPERTIES OF LIPASE}

\section{The $\mathrm{pH}$}

Most of the microbial lipases are neutral or acidic at their optimum activity. Alkaline lipases, which are stable at $\mathrm{pH}$ range of 8-10 offer promising applications in many upcoming bio-based industries such as textile, detergent, etc. Lipase from Aspergillus carneus, Bacillus thermoleovorans, Bacillus stearothermophilus, Fusarium oxysporum were found stable at the $\mathrm{pH}$ range 8-10 (Castro-Ochoa et al. 2005; Prazeres et al. 2006; Sinchaikul et al. 2001) whereas lipase produced by Rhizopus oryzae, Cryptococcus sp. showed the maximum activity at the pH range 7-8 (Hiol et al. 2000; Kamini et al. 2000).

\section{Temperature}

Generally, most of the microbial lipases are mesophilic in nature, i.e., the optimum temperature for their maximum activity ranges from 30 to $50{ }^{\circ} \mathrm{C}$, but the increased demand for thermotolerant lipases in industries has led to the exploration of many microbial species producing thermophilic lipases, most of which retained $70-100 \%$ of the activity even at the temperature range $50-70{ }^{\circ} \mathrm{C}$ (Bora \& Bora 2012; Gohel et al. 2013; Khalil 2013); for instance, the lipase from Bacillus sp. (an isolate from the hot spring) retained $90 \%$ activity at $60{ }^{\circ} \mathrm{C}$ and $70 \%$ of activity at $70{ }^{\circ} \mathrm{C}$ for $1 \mathrm{~h}$ (Bora \& Bora 2012), whereas the lipase from Pseudomonas sp. strain $\mathrm{ZBC} 1$ showed the optimum activity at $80{ }^{\circ} \mathrm{C}$ (Xing et al. 2013). Cold active lipases are active at $10-25{ }^{\circ} \mathrm{C}$, and they facilitate gentle and efficient industrial applications by significantly reducing energy consumption. Many microbes such as Rhodococcus cercidiphylli BZ22, Penicillium expansum, Yarrowia lipolytica, Stenotrophomonas maltophilia, Pseudoalteromonas sp. etc. isolated from the harsh environments produced lipases that are active at low temperatures (Mohammed et al. 2013; Park et al. 2013; Sathish Yadav et al. 2011; Wang et al. 2012; Yu \& Margesin 2014).

\section{Effectors}

Usually metal ions can alter the efficacy of an enzyme either by enhancing or by inhibiting the activity. Divalent metal cations such as $\mathrm{Ca}^{2+}, \mathrm{Cd}^{2+}, \mathrm{Fe}^{2+}$, etc . enhance the activity of lipases, among which $\mathrm{Ca}^{2+}$ plays a critical role in stabilizing the enzyme under detrimental conditions (El Khattabi et al. 2003; Verma et al. 2012). Some other cations such as $\mathrm{Co}^{2+}, \mathrm{Zn}^{2+}, \mathrm{Mn}^{2+}$, and $\mathrm{Mg}^{2+}$ have mild to strong inhibitory effect on lipase activity (Kumar et al. 2005). Generally, detergents such as tween 80, tween 20 and sodium dodecylsulphate (SDS) were shown to have inhibitory effects on lipase activity; whereas triton X-100 enhanced the activity (Castro-Ochoa et al. 2005).

\section{Specificity}

Specificities of lipases play a crucial role in their possible applications in analytical and industrial purposes, especially in pharmaceutic industry. Majority of the lipases show substrate or regio- or enantio-specificites, which are highly determined by the size, shape and hydrophobicities of the binding pockets located in the active site. Some of the lipases, specifically act on tri-, di-, monoglycerides and other esters. Non-specific lipase completely hydrolyze the triglycereides to fatty acids and glycerol, but most of the extracellular lipases are regiospecific especially at 1, 3 positions. Lipase from Burkholderia cepacia found applications in organic synthesis due to its enantiospecificities, preferably the $(R)$ - enantiomer over the $(S)$ - forms (Jaeger et al. 1999).

\section{Interfacial activation}

Lipase exhibits a characteristic property, called interfacial activation which makes it a suitable catalyst in water-oil medium, i.e., the activity of the enzyme is highly increased when the substrates form emulsion in the reaction media. In aqueous medium, the active site of enzyme is covered by a loop of peptide called 'lid', but contact with the interfacial area induce drastic conformational changes on to the active site, so that the lid moves aside facilitating the enzyme- substrate reaction (Dheeman 2011).

\section{Active site of lipase}

The crystalline structures of many bacterial lipases have been elucidated to date, among which most of them shared a common folding pattern known as $\alpha / \beta$ hydrolase (Figure 1). Generally, $\alpha / \beta$ hydrolase consists of $\alpha$ helices $(\alpha \mathrm{A}-\alpha \mathrm{F})$ packed on either sides of a central beta sheet. The central $\beta$ sheet is made of 8 parallel strands $(\beta 1-\beta 8)$, except the second strand which is in antiparallel direction. The active site of lipase consists of 3 catalytic residues (the triad), a nucleophilic residue, a catalytic acid residue and a histidine residue. In lipases, the nucleophile is invariably serine, whereas the catalytic acid is either an aspartate or glutamate. The topological position of the nucleophilic residue is often after $\beta 5$ strand, the Asp/Glu residue is after $\beta 7$ strand and the histidine residue is after $\beta 8$ strand (Jaeger et al. 1999) (Figure 1). In most of the lipases, the 'lid/hood' or the flexible fragment is made of one or two alpha helices, which covers the active site at the inactive state of the enzyme. In the presence of hydrophobic substrates, the enzyme undergoes interfacial activation so that the conformational changes at the active site make the lid open, so as to facilitate the entry of substrates to the catalytic residues (Pleiss et al. 1998).

The geometry of the active sites of lipases varies widely and determines the biochemical properties of the enzyme. Generally, it is a deep hydrophobic pocket which exactly fits scissile fatty acids of substrates into it. According to the shapes of the bindings sites, lipase can be categorized into three; lipase with creviceshaped (Rhizomucor and Rhizopus), funnel-shaped (Pancreatic lipase, lipase B from, Candida antarctica, Pseudomonas), and tunnel-shaped (C. rugosa, Geotrichum candidum) (Pleiss et al. 1998) (Figure 2). 


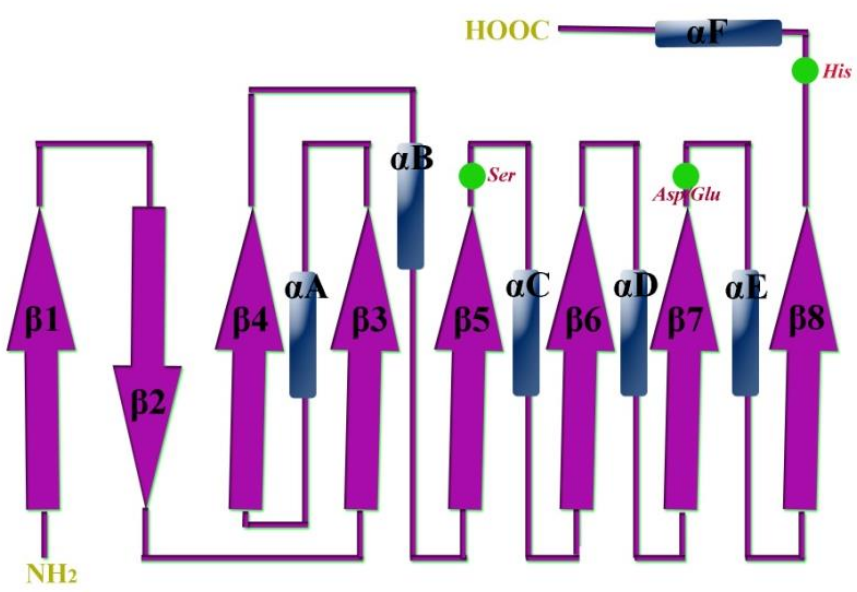

Figure 1 Structure of $\alpha / \beta$ hydrolase
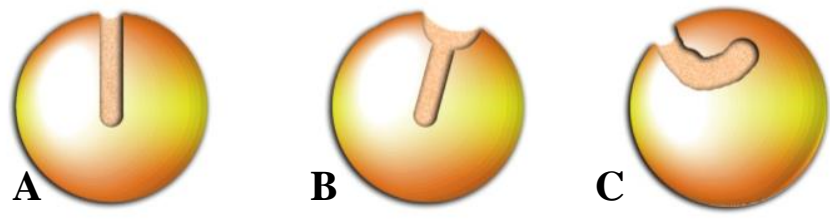

Figure 2 Different shapes of lipase active site A) tunnel -like B) funnel -like C) crevice-like

\section{CLASSIFICATION OF LIPASE}

Most of the lipases possess a consensus sequence of Gly-x-Ser-x-Gly around the serine residue situated at the active site. But advances on their crystalline studies and sequence analyses revealed the existence of other motifs also. Thus, based on their sequence homology and functional properties, lipases are classified into 8 major groups, among which the first largest family is again classified into 6 subfamilies (Arpigny \& Jaeger 1999; Bornscheuer 2002) (Table 3).

Table 3 Classification of lipases

\begin{tabular}{|c|c|c|}
\hline Family & Subfamily & Microorganism \\
\hline \multirow[t]{22}{*}{$\mathrm{I}$} & 1 & Pseudomonas aeruginosa \\
\hline & & Pseudomonas fluorescens $C 9$ \\
\hline & & Vibrio cholerae \\
\hline & & Acinetobacter calcoaceticus \\
\hline & & Pseudomonas fragi \\
\hline & & Pseudomonas wisconsinensis \\
\hline & & Proteus vulgaris \\
\hline & 2 & Burkholderia glumae \\
\hline & & Chromobacterium viscosum \\
\hline & & Burkholderia cepacia \\
\hline & & Pseudomonas luteola \\
\hline & 3 & Pseudomonas fluorescens SIK WI \\
\hline & & Serratia marcescens \\
\hline & 4 & Bacillus subtilis \\
\hline & & Bacillus pumilus \\
\hline & 5 & Bacillus stearothermophilus \\
\hline & & Bacillus thermocatenulatus \\
\hline & & Staphylococcus hyicus \\
\hline & & Staphylococcus aureus \\
\hline & & Staphylococcus epidermidis \\
\hline & 6 & Propionibacterium acnes \\
\hline & & Streptomyces cinnamoneus \\
\hline \multirow[t]{5}{*}{ II } & & Aeromonas hydrophila \\
\hline & & Streptomyces scabies \\
\hline & & Pseudomonas aeruginosa \\
\hline & & Salmonella typhimurium \\
\hline & & Photorhabdus luminescens \\
\hline \multirow[t]{3}{*}{ III } & & Streptomyces exfoliatus \\
\hline & & Streptomyces albus \\
\hline & & Moraxella sp. \\
\hline \multirow[t]{6}{*}{ IV } & & Alicyclobacillus acidocaldarius \\
\hline & & Pseudomonas sp. B11-1 \\
\hline & & Archaeoglobus fulgidus \\
\hline & & Alcaligenes eutrophus \\
\hline & & Escherichia coli \\
\hline & & Moraxella sp. \\
\hline V & & Pseudomonas oleovorans \\
\hline
\end{tabular}

Haemophilus influenzae Psychrobacter immobilis Moraxella sp.

Sulfolobus acidocaldarius Acetobacter pasteurianus

VI

Synechocystis sp.

Spirulina platensis

Pseudomonas fluorescens

Rickettsia prowazekii

Chlamydia trachomatis

VII

Arthrobacter oxydans

Bacillus subtilis

Streptomyces coelicolor

VIII

Arthrobacter globiformis

Streptomyces chrysomallus

Pseudomonas fluorescens SIK W1

Source: (Arpigny \& Jaeger 1999)

\section{LIPASE SECRETION PATHWAYS}

Lipases are extracellular enzymes, and are to be transported across the cell membrane to reach their final destination. In Gram-positive bacteria, secreted enzymes have to cross just a single cytoplasmic membrane whereas in Gramnegative bacteria, it has to be translocated through the periplasm and outer membrane (Jaeger $\boldsymbol{e t}$ al. 1999). A series of complex transporter proteins play crucial roles in the transportation of lipase through the membrane. Two major secretory pathways have been identified (represented as type I and II), of which lipases can utilize at least one of them (Jaeger \& Eggert 2002). Type I pathway is mainly mediated by $\mathrm{ABC}$ transporters, whereas secreton mediates the type II. Lipases produced by $P$. fluorescence and Serratia marcescens display a Cterminal secretion signal located in the last 60 amino acids, and is not cleaved during secretion. The signal sequence specifically recognizes the ABC protein, triggering the assembly of the functional trans-envelope

complex (Delepelaire 2004). Type I secretory pathway via $\mathrm{ABC}$ transporters generally consists of three major membrane proteins, i.e., the inner membrane ATPase [ATP-binding cassette (ABC) superfamily], the second protein named membrane-fusion-protein (MFP) anchored to the inner membrane with a large hydrophilic domain facing the periplasm, and a C-terminal domain presumably interacting with the outer membrane. The third component is an outer membrane protein (OMP) (Figure 3). The assignment of different proteins as these exporters may vary depending on the species. S. marcescens, the most studied bacterium for type I secretion of lipase, possess a signal peptide that is rich in glycine and comprises of nine-residue sequence Gly-Gly-X-Gly-X-Asp-X-U-X (where $\mathrm{X}$ is any amino acid and $U$ is a large hydrophobic amino acid). It utilizes LipB as ABC protein, LipC as the MFP component which mediates contact with both the inner and the outer membrane, and LipD as the OMP component (Akatsuka et al. 1995; Jaeger \& Eggert 2002). AprD, AprE and AprF are necessary proteins acting as ABC, MFP and OMP, respectively for the efficient secretion of lipase by $P$. fluorescence (Duong et al. 1994). The exporter constituted by these proteins forms a multiprotein complex across the periplasm for tranlocating lipase from the cytoplasm to extracellular space without forming any active periplasimic enzyme intermediates. Over expression of the $\mathrm{ABC}$ exporter provides a considerable increase in the secretion of the lipase, and therefore an increased yield of extracellular lipase protein (Ahn et al. 2001).

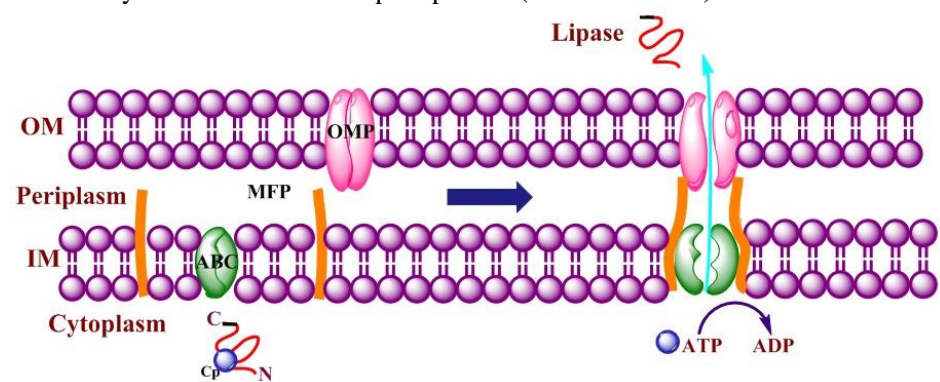

Figure 3 Type I secretory pathway of lipase via $\mathrm{ABC}$ transporters

The type II secretory pathway is generally known as sec-dependent pathway, which was found involved in the secretion of lipase in bacteria like $P$. aeruginosa and Bacillus spp. Many lipases of both Gram-positive and Gramnegative bacteria possess an $\mathrm{N}$-terminal signal sequence and are secreted via type II pathway. It consists of two steps: proteins are first translocated across the inner membrane by the general secretory pathway (Cao et al. 2014) or twin-arginine translocation (Tat) pathway, and subsequently transported from the periplasm to the exterior of the outer membrane in an extremely short period (Figure 4). In Gram-positive bacteria, secreted enzymes have to cross just a single cytoplasmic membrane. Usually, these proteins contain a signal sequence, which directs their translocation via the Sec or Tat translocase, the multi-subunit proteins identified 
in Bacillus spp. However, lipases from Gram-negative bacteria do have to cross a second barrier constituted by the outer membrane. In $P$. aeruginosa, the prolipase exported to the periplasmic space by Sec machinery, fold in the periplasm into an enzymatically active conformation with the help of specific intermolecular chaperones called Lif proteins (lipase-specific foldases). Subsequently, they are transported through the outer membrane by means of a complex machinery called secreton, consisting of up to 14 different proteins. Similar multi component secretons have been identified in lipase produced by $P$. alcaligenes, Aeromonas hydrophila, Xanthomonas campestris and Vibrio cholera (Jaeger \& Eggert 2002).

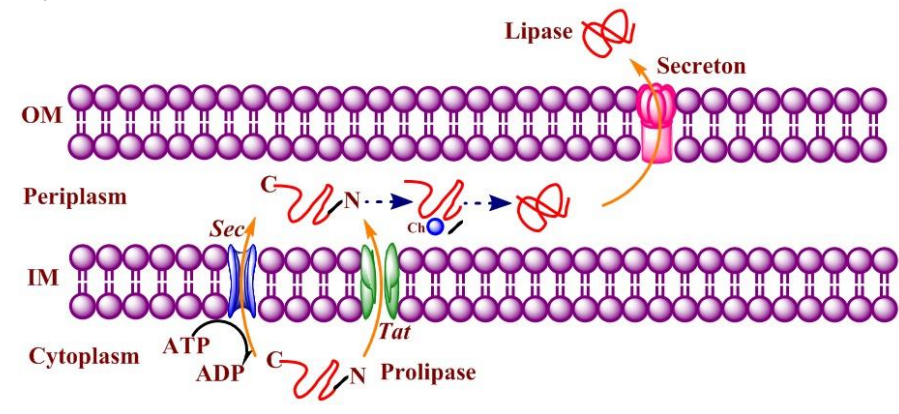

Figure 4 Type II secretory pathway of lipase mediated by Sec or Tat translocase

In $P$. aeruginosa, autotranspoters also mediate the transport of enzymes across the outer membrane. These autotransporters form channels spanning in the outer membrane, which is usually made up of a $\beta$-barrel composed of nearly $14 \beta$ sheets and hold the enzyme in close contact to, or even firmly bound to the surface of the cell exposing its catalytic domain (Rosenay \& Jaeger, 2000).

\section{APPLICATIONS OF LIPASE}

Microbial lipases claim a wide variety of industrial applications due to the ease for mass production and versatile specificities. Based on total volume of sales, lipases occupy the third largest group of enzymes next to proteases and carbohydrases. The commercial use of lipases is a billion-dollar business and their applications are highly dependent on specificities, optimum $\mathrm{pH}$, temperature, tolerance to organic solvents, etc. Lipases form an integral part of the industries ranging from food and fats, dairy, organic chemicals, pharmaceuticals, leather, environmental management, agrochemicals, detergents, oleo-chemicals, tea, cosmetics, and in several bioremediation processes (Verma et al. 2012)

\section{Food and dairy industry}

Lipases are widely used in food industries for the hydrolysis or modification of biomaterials. Egg white is an important ingredient of many bakery products such as cakes, bread, etc. Contamination of egg white with lipids decreases the desirable foaming ability of the product. Therefore, lipase is used to remove the lipid contamination and to improve the quality of dough and to achieve an even, light-coloured crust on the products and a soft texture. Treatment of egg yolk with phospholipase hydrolyzes egg lecithin and iso-lecithin, thereby improving emulsifying capacity and heat stability, which can be used to make myonnaise, custards, baby foods, etc. (Buxmann et al. 2010). Lipases can enhance the flavor of bakery products by synthesizing esters of short-chain fatty acids and alcohols (Alves Macedo et al. 2003). Lipases can also be used in degumming of vegetable oils during the process of refining. The degumming process removes the phospholipid impurities from the crude vegetable oils which may otherwise pose many problems for the storage and processing of vegetable oils from soybean, sunflower and rape seed; for instance, lipase produced by genetically modified Aspergillus oryzae (Lecitase ${ }^{\circledR}$ Ultra) was used for the degumming of rapeseed and soybean oils, which removed more than $90 \%$ of phospholipids within $5 \mathrm{~h}$ at $50{ }^{\circ} \mathrm{C}$ (Yang et al. 2006). Biolipolysis is being used to make fat free meat and fish. The controlled application of lipase to wheat flour produces different variations of quality; thereby noodles and pasta are given an even and intense color, and their stickiness when overcooked is reduced (Menzi 1970; Søe $\boldsymbol{e t}$ al. 2005). Genetically engineered baker's yeast (Saccharomyces cereviciae) with bacterial lipase gene LIP A resulted in higher productivity of lipase and found application in bread making as a technological additive (Sánchez et al. 2002).

Lipases are extensively used in dairy industry for the hydrolysis of milk fat to improve the flavor of cheese, butter, fat and cream. Enzyme modified cheese technology is now gaining importance for making a variety of cheese with desired flavor and aroma; in this process lipase is generally used under controlled conditions in combination with other hydrolytic enzymes such as protease and amylase. It reduces the bitterness as well as ripening time and modifies flavor intensity (Aminifar \& Emam-Djomeh 2014). For instance, commercial microbial lipase (Piccantase A) enhances the flavor development during the ripening stage of Talum cheese (Yilmaz et al. 2005). Extracellular lipase produced by Cryptococcus flavescens 39-A releases short-chain fatty acids
$\left(\mathrm{C}_{4}-\mathrm{C}_{6}\right)$ in milk fat during the mozzarella cheese-making process and produce a favorable cheese flavor (Mase $\boldsymbol{e t}$ al. 2013). Penicillium roqueforti, the lipolytic activities of which contributes to the characteristic flavor and blue-green veined appearance to blue cheese (Cao et al. 2014). Likewise, lipases enhance the flavors of natural milk fat producing volatile flavoring compounds (Omar et al. 2015). Lipases are widely used to produce novel fats through the process of hydrolysis, esterification and inter-esterification. Lipases modify the properties of lipids by altering the positions of fatty acid chains or by adding or removing one or more fatty acids to the glycerides. The position, chain length and degree of unsaturation greatly influence not only the physical properties, but also the nutritional and sensory value of a given triglyceride as well. Thus, high value fats and oils can be synthesized from cheap resources. For example, cocoa butter fat often used in bakery foods, is often in short supply and the price can fluctuate widely. Lipase from Mucor miehei can effectively be utilized to produce cocoa butter like fat from palm olein and distillate from palm oil refinery which contribute to the flavor of chocolate, caramels, toffees and butter creams (Mohamed 2012). In coffee whiteners, lipases assist in imparting a rich creamy flavor (Godfrey, 1982).

\section{Processing of fats and oil}

Processing of fats and oils by the enrichment of specific fatty acids or hydrolysis of triglycerides to release fatty acids or by altering the location of fatty acids is an important application of lipase. It enables the commercial exploitation of naturally produced renewable raw materials such as oils from corn, rapeseed, sunflower, palm, coconut, olives, rice bran, and a wide range of animal fats. Wax esters, esters of long chain fatty acids and alcohols $(C \geq 12)$ are widely used in lubricant, pharmaceutical, cosmetic and plasticizer industries, which are usually extracted from expensive spermaceti oil and jojoba oil for commercial applications. Lipase mediates the synthesis of wax esters from cheap oils, for instance, immobilized lipase from Candida sp. synthesizes the wax ester, cetyl oleate, from oleic acid and cetyl alcohol with over 96\% purity (Deng Li $\boldsymbol{e t}$ al 2011). Lipase catalyzes the hydrolysis of salmon oil to increase its omega-3 polyunsaturated fatty acids (PUFA) content. It was observed that lipase from $C$. rugosa increased omega-3 PUFA content by 2.5 folds (Kahveci et al. 2010; Kahveci \& Xu 2011). Similarly, microbial lipases, from $C$. rugosa, $C$. cylindracea, Mucor javanicus and Aspergillus niger were used for the enzymatic hydrolysis of sardine oil to increase the content of omega-3 PUFAs by $10-35 \%$ (Okada \& Morrissey 2007). Production of biodiesel consisting of methyl esters (methanolysis) of long chain fatty acids is yet another promising application of lipase which, has been widely exploited all over the world. In such cases immobilized lipase was used, which offers repeated usage of the enzyme without losing its specificity. The enzymatic production of biodiesel by methanolysis of cottonseed oil was studied using immobilized lipase from $C$. antarctica as catalyst in $t$-butanol solvent, in which the ester yield was about 95-97\% (Royon et al. 2007). Lipase producing whole cells of Rhizopus oryzae was employed for the production of biodiesel employing the low cost non-edible oil from the seeds of Jatropha curcas. A variety of low cost vegetable oils such as sunflower oil, soybean oil, karanj oil, etc. can effectively be used to produce biodiesel by lipase mediated hydrolysis (Dizge et al. 2009; Kaieda et al. 2001; Modi et al. 2007; Noureddini et al. 2005). Recently, it is demonstrated that lipase from Bacillus spp. can be used for the biotransformation of fungal lipids into cost-competitive biodiesel (Abd-Alla et al. 2015).

\section{Detergents}

Now-a-days enzymes have become the key constituents of detergent formulations, of which lipases play an important role for the removal of tough fatty stains such as butter, oil, etc. from the fabric that are hard to remove under normal washing. For the last two decades, detergent industry has become one of the biggest markets of microbial lipases, because of their functional importance for the removal of fatty residues in laundry, dishwashers and for cleaning of clogged stains. Addition of these enzymes not only improves the performance of detergents but also offers better ecological acceptance and produce effluent with lower COD and corrosive nature (Nerurkar et al. 2013). Standard wash liquids contain anionic and nonionic surfactants, oxidants, and complexing agents at a $\mathrm{pH}$ of about 10 and temperatures around $35-45{ }^{\circ} \mathrm{C}$, which is a rather hostile environment for enzymes. As a result, massive screening is required to find out suitable enzymes exhibiting low substrate specificity, stability under alkaline $\mathrm{pH}$ (8-11), elevated temperature $\left(30-60{ }^{\circ} \mathrm{C}\right)$, and also compatibility with other ingredients of formulations such as metals, oxidants, surfactants etc. Bacterial lipase from Staphylococcus arlettae JPBW-1 isolated from the rock salt mine has been assessed for its use in laundry formulations which exhibited good stability towards surfactants and oxidizing agents, and removed about $62 \%$ of olive oil from cotton fabrics (Chauhan et al. 2013). A novel alkaline lipase from Burkholderia cepacia RGP-10 exhibited better stability towards commercial detergents and oxidizing agents than Lipolase ${ }^{\circledR}$ (Rathi et al. 2001). Application of cold active lipase in detergent formulations allows laundering at low temperatures and reduces the energy expenditure. Recently, many cold-active lipases have been reported in bacteria such as Pseudoalteromonas sp. NJ 70 
(Wang et al. 2012), Bacillus sphaericus (Joseph \& Ramteke 2013) Microbacterium luteolum (Joseph et al. 2012), Pichia lynferdii (Park et al. 2013), etc. Most of them are active at temperature ranging from $0-30{ }^{\circ} \mathrm{C}$, and showed good tolerance to salt, synthetic surfactants and oxidizing agents. Lipolase, the first industrial lipase was obtained from Humicola lanuginose, which was marketed by Novozymes (Denmark). Later on three genetically modified commercial lipases such as LipoPrime, Lipolase Ultra, Lipex were also marked by expressing the lipase gene of Humicola lanuginose in Aspergillus oryzae, a fungus. Many other detergent lipases are available on the market and some of them are listed in Table 4.

Table 4 Commercial lipases used in detergent industry

\begin{tabular}{|c|c|c|c|}
\hline Trade name & Source & Supplier & Expression \\
\hline Lipolase ${ }^{\circledR}$ & Humicola lanuginosa & Novozymes & Aspergillus oryzae \\
\hline LipoPrime $^{\mathrm{TM}}$ & Protein engineered variant of lipolase & Novozyme & Aspergillus oryzae \\
\hline Lipolase Ultra ${ }^{\circledR}$ & Protein engineered variant of lipolase & Novozymes & Aspergillus oryzae \\
\hline Lipex® & Protein engineered variant of lipolase & Novozymes & Aspergillus oryzae \\
\hline Lipomax $^{\mathrm{TM}}$ & Pseudomonas alcaligenes & Genencor Inc. & Pseudomona alcaligenes \\
\hline Lipase P & Pseudomonas fluorescens & $\begin{array}{l}\text { Amano Pharmaceutical } \\
\text { Co. Ltd }\end{array}$ & Pseudomonas fluorescens \\
\hline Luma fast & Pseudomonas mendocina & Genencor, USA & Bacillus sp. \\
\hline
\end{tabular}

\section{Leather industry}

These days, enzymes are widely used for the processing of hides and skins in leather industry. Lipase and proteases are the most important enzymes which found applications during bating, soaking, dehairing and degreasing of skin (Dayanandhan et al. 2003; Hasan et al. 2006). During bathing, the enzymes enhance water uptake, loosen the scud and disperse fats and oils together with dirt and other materials present on the skin. Lipase specifically degrades fat but do not damage the leather which is proteinaceous in nature, it hydrolyses the fat on the outside of the hides and skins as well as inside the skin structure. Thus, lipase assisted treatment of leather gives the leather with far better quality and finish with uniform color and cleaner appearance as compared to conventional chemical agents. Lipase also improves the production of hydrophobic waterproof leather, which represents an environment friendly method of leather processing. It was found that the lipase produced by $B$. subtilis can be used for the degreasing process, thereby removing all the fat within $8-12 \mathrm{~h}$ of incubation by maintaining natural skin colour (Saran, 2013). NovoLime, a protease/lipase blend for enzyme-assisted liming of hides and skins, and NovoCor AD, an acid lipase for degreasing of hides and skins, are some of the commercially available lipases for the leather industry.

\section{Pharmaceutics}

Applications of lipase for the synthesis of chiral drugs, kinetic resolution of racemic alcohols, acids, esters or amines are well established. Synthesis of diltiazem hydrochloride, a calcium antagonist (a coronary vasodilator), using lipase mediated asymmetric hydrolysis of trans-3-(4-methoxyphenyl) glycidic acid methyl ester [( \pm -MPGM] was found to be a more efficient process compared to the conventional chemical synthesis, for which lipase from Serratia marcescens was generally employed (Matsumae et al. 1993). Lipase from $C$. rugosa immobilized on a nylon scaffold was used to synthesize lovastatin, a drug lowering the serum cholesterol levels, by the regioselective acylation of a diol lactone precursor with 2-methylbutyric acid in mixtures of organic solvents (Yang et al. 1997). Lipase from Pseudomonas sp. AK mediated the kinetic resolution of the chiral silane reagents used for the synthesis of a potent antitumor agent called epothilone A (Zhu \& Panek 2001).

\section{Pulp and paper}

The paper industry utilizes huge amount of lignocellulose every year Historically, the enzymatic applications in paper industry was confined to the treatment of raw starch; but, later in since 1990s, lipase mediated removal of pitch has become an essential process of large-scale paper making process 'Pitch' or 'resin stickies' is a term used to collectively describe the hydrophobic components of wood such as triglycerides, waxes, etc. (Farrell et al. 1997). Pitch and related substances, which usually create major problems to the machines and cause holes and spots in the final paper, are common in paper mills. It may reduce the production levels and increase equipment maintenance as well as operation costs. Nippon paper Industries, in Japan, have developed a pitch control method that uses the C. rugosa fungal lipase to hydrolyze up to $90 \%$ of the wood triglycerides (Arpigny \& Jaeger 1999, Jaeger \& Reetz 1998). Lipase in paper industry decreases chemical usage thereby reducing pollution level of waste water. It provide prolonged equipment life as lipase removes sticky deposits in the paper machines, save energy and time and reduce composite cost (Farrell $\boldsymbol{e t}$ al. 1997). The addition of lipase from Pseudomonas sp. (KWI-56) to a deinking composition for ethylene oxide-propylene oxide adduct stearate improved whiteness of paper and reduced residual ink spots (Fukuda et al. 1990, Gandhi 1997). Lipase from Thermomyces lanuginosus was immobilized on the resin coated with chitosan along with pectinase, which reduced the pitch deposits in white water by 74\% (Liu et al. 2012a). Similarly, alkaline lipase was found to be efficient for removing pitch from the recycled fiber pulping waste water (Liu $\boldsymbol{e t}$ al. 2012b).

\section{Cosmetics}

Recently, lipases found applications in producing many cosmetic ingredients such as retinol, natural dyes, etc. For the cosmetic industry, the natural product are always of interest as people demands those products which improve not just the appearance of the skin, but the health of the skin as well. Vitamin A (retinol), vitamin $\mathrm{C}$ (ascorbic acid), and derivatives combat many skin disorders including photoaging, psoriasis and acne (Adamczak \& Bornscheuer 2009). Lipase catalyzed synthesis of retinyl esters has become popular as the chemical synthesis meets some serious defects and offers mild reaction conditions, high catalytic efficiency, inherent selectivity, and much purer products (Maugard \& Legoy 2000, Maugard et al. 2000, Moreno-Perez et al. 2013). Lipase from $C$. antarctica efficiently catalyzes the trans-esterification between glycerides and vitamins to produce retinyl/ ascorbic esters (Lerin et al. 2012; Moreno-Perez et al. 2013; Reyes-Duarte et al. 2011; Sun et al. 2013). Immobilized lipase catalyzes the synthesis of retinyl L-lactate by the trans-esterification reaction between retinol and L-methyl lactate, and the synthesis of ascorbyl L-lactate by the trans-esterification of ascorbic acid with L-methyl lactate, with yield over $90 \%$ and $80 \%$, respectively (Maugard et al. 2000). Lipase from C. antartica also mediated the trans-esterification between olive oil and ascorbic acid to produce liposoluble ascorbyl oleate, which is widely used as an antioxidant (Moreno-Perez et al. 2013).

Lipases also found applications in the production of natural dyes such as indigo and its derivatives, water soluble dyes of interest for cosmetics. Lipase releases indoxyl from istan $\mathrm{B}$ which in combination with isatan $\mathrm{C}$ can be processed to produce indigo (Maugard et al. 2002). Aroma esters consisting of short chain fatty acids and alcohol are synthesized by the direct application of lipase, which provides natural fragrance to the cosmetics. In 2001, Gatfield et al. reported a method to produce natural ethyl (E,Z)-2,4-decadienoate, the compound of pear by lipase mediated trans-esterification of stillingia oil with ethanol (Gatfield $\boldsymbol{e t}$ al. 2001).

\section{CONCLUSIONS}

Global enzyme market is expected to rise by $7 \%$ in 2015 . Growing trends in the world market of biocatalysts indicate that, developed countries in North America would be the largest consumers followed by Western Europe. Their stringent government rules and regulations made them to adopt green technologies in industries to address the environmental issues as well as to improve the product quality and acceptability. Industrial processes demand enzymes with unique specificities and high performance which attracts the attention of researchers and industrialists to produce novel enzymes to minimize the cost. Application of lipases is broadening up rapidly, due their remarkable potential for accomplishing innumerable novel reactions, both in aqueous and non-aqueous environments Hence, the demand for the production and characterization of new lipases is stil increasing significantly. Though many microbial lipases have been explored for their mode of actions, the high cost of production and purification hinders its world-wide commercialization. Moreover, it is necessary to elucidate the reaction mechanism of lipases - both general and type-wise in tune with the specific need in industry, mode of control and regulated expression to meet the future needs and to hit the anticipated level of commercial demand.

Acknowledgements: The authors gratefully acknowledge the Kerala State Council for Science, Technology and Environment, Government of Kerala for a research grant (No. 447/2013/KSCSTE).

\section{REFERENCES}

ABBAS, H., HIOL, A., DEYRIS, V., COMEAU, L. 2002. Isolation and characterization of an extracellular lipase from Mucor sp. strain isolated from palm fruit. Enzyme and Microbial Technology, 31, 968-75. http://dx.doi.org/10.1016/S0141-0229(02)00190-4 
ABD-ALLA, M. H., BAGY, M. M. K., MORSY, F. M., HASSAN, E. A. 2015. Improvement of fungal lipids esterification process by bacterial lipase for biodiesel synthesis. Fuel, 160

196-204. http://dx.doi.org/10.1016/j.fuel.2015.07.080

ABRAMIĆ, M., LEŠČIÍ, I., KORICA, T., VITALE, L., SAENGER, W. PIGAC, J. 1999. Purification and properties of extracellular lipase from Streptomyces rimosus. Enzyme and Microbial Technology, 25 , 522-29.http://dx.doi.org/10.1016/S0141-0229(99)00077-0

ADAMCZAK, M., BORNSCHEUER, U. T. 2009. Improving ascorbyl oleate synthesis catalyzed by Candida antarctica lipase B in ionic liquids and water activity control by salt hydrates. Process Biochemistry, 44 257-61.http://dx.doi.org/10.1016/j.procbio.2008.10.014

ADINARAYANA, K., RAJU, K., ZARGAR, M. I., DEVI, R. B., LAKSHMI, P. J., ELLAIAH, P. 2004. Optimization of process parameters for production of lipase in solid-state fermentation by newly isolated Aspergillus species. Indian journal of Biotechnology, 3, 65-69.

AHN, J. H., PAN, J. G., RHEE, J. S. 2001. Homologous expression of the lipase and $\mathrm{ABC}$ transporter gene cluster, tliDEFA, enhances lipase secretion in Pseudomonas spp. Applied and environmental microbiology, 67 5506-11.http://dx.doi.org/10.1128/AEM.67.12.5506-5511.2001

AKATSUKA, H., KAWAI, E., OMORI, K., SHIBATANI, T. 1995. The three genes lipB, lipC, and lipD involved in the extracellular secretion of the Serratia marcescens lipase which lacks an N-terminal signal peptide. Journal of bacteriology, 177, 6381-89.

ALVES MACEDO, G., SOBERÓN LOZANO, M. M., PASTORE, G. M. 2003. Enzymatic synthesis of short chain citronellyl esters by a new lipase from Rhizopus sp. Electronic Journal of Biotechnology, 6 , 3-4.http://dx.doi.org/10.4067/S0717-34582003000100009

AMINIFAR, M., EMAM-DJOMEH, Z. 2014. Changes of texture, microstructure and free fatty acid contents of lighvan cheese during accelerated ripening with lipase. Journal of Agricultural Science and Technology, 16, 113-23.

ARAVINDAN, R., ANBUMATHI, P., VIRUTHAGIRI, T. 2007. Lipase applications in food industry. Indian Journal of Biotechnology, 6, 141.

ARPIGNY, J., JAEGER, K. 1999. Bacterial lipolytic enzymes: classification and properties. Biochemical Journal, 343, 177-83.

BALAJI, V., EBENEZER, P. 2008. Optimization of extracellular lipase production in Colletotrichum gloeosporioides by solid state fermentation. Indian Journal of Science and Technology,

1-8.http://dx.doi.org/10.17485/ijst/2008/v1i7/29600

BENJAMIN, S., PANDEY, A. 1996. Optimization of liquid media for lipase production by Candida rugosa. Bioresource Technology, 55 , 167-70.http://dx.doi.org/10.1016/0960-8524(95)00194-8

BENJAMIN, S., PANDEY, A. 1998. Candida rugosa lipases: molecular biology and versatility in biotechnology. Yeast, 14, 1069-87.http://dx.doi.org/10.1002/(SICI)10970061(19980915)14:12<1069::AID -YEA303>3.0.CO;2-K

BENJAMIN, S., PANDEY, A. 2000. Isolation and characterization of three distinct forms of lipases from Candida rugosa produced in solid state fermentation. Brazilian Archives of Biology and Technology, 43 , 453-60.http://dx.doi.org/10.1590/S1516-89132000000500002

BORA, L., BORA, M. 2012. Optimization of extracellular thermophilic highly alkaline lipase from thermophilic Bacillus sp isolated from Hotspring of Arunachal Pradesh, India. Brazilian Journal of Microbiology, 43 , 30-42.http://dx.doi.org/10.1590/S1517-83822012000100004

BORNSCHEUER, U. T. 2002. Microbial carboxyl esterases: classification, properties and application in biocatalysis. FEMS microbiology reviews, 26 , 73-81.http://dx.doi.org/10.1111/j.1574-6976.2002.tb00599.x

BROZZOLI, V., CROGNALE, S., SAMPEDRO, I., FEDERICI, F. D'ANNIBALE, A., PETRUCCIOLI, M. 2009. Assessment of olive-mil wastewater as a growth medium for lipase production by Candida cylindracea in bench-top reactor. Bioresource technology,

3395-402.http://dx.doi.org/10.1016/i.biortech.2009.02.022

BUSSAMARA, R., FUENTEFRIA, A. M., OLIVEIRA, E. S. D., BROETTO, L., SIMCIKOVA, M., et al.. 2010. Isolation of a lipase-secreting yeast for enzyme production in a pilot-plant scale batch fermentation. Bioresource technology, 101, 268-75. http://dx.doi.org/10.1016/j.biortech.2008. 10.063

BUXMANN, W., BINDRICH, U., HEINZ, V., KNORR, D., FRANKE, K. 2010. Influencing emulsifying properties of egg yolk by enzymatic modification by phospholipase D from Streptomyces chromofuscus: Part 1: Technological properties of incubated egg yolk. Colloids and Surfaces B: Biointerfaces, 76, 186-91.http://dx.doi.org/10.1016/j.colsurfb.2009.10.032

CAO, M., FONSECA, L. M., SCHOENFUSS, T. C., RANKIN, S. A. 2014 Homogenization and lipase treatment of milk and resulting methyl ketone generation in blue cheese. Journal of agricultural and food chemistry, 62(25), 5726-5733.http://dx.doi.org/10.1021/jf4048786

CASTRO-OCHOA, L. D., RODRÍGUEZ-GÓMEZ, C., VALERIO-ALFARO G., OLIART ROS, R. 2005. Screening, purification and characterization of the thermoalkalophilic lipase produced by Bacillus thermoleovorans CCR11. Enzyme $\begin{array}{llll}\text { and Microbial } & \text { Technology, }\end{array}$ http///dx doi org/101016/ienzmictec 2005.06 .003
CHAUHAN, M., CHAUHAN, R. S., GARLAPATI, V. K. 2013. Evaluation of a new lipase from Staphylococcus sp. for detergent additive capability. BioMed research international, 2013.http://dx.doi.org/10.1155/2013/374967

COLEN, G., JUNQUEIRA, R. G., MORAES-SANTOS, T. 2006. Isolation and screening of alkaline lipase-producing fungi from Brazilian savanna soil. World Journal of Microbiology and Biotechnology, 22, 881-85.http://dx.doi.org/10.1007/s11274-005-9118-9

COSTA, M. A. F., PERALTA, R. M. 1999. Production of lipase by soil fungi and partial characterization of lipase from a selected strain (Penicillium wortmanii) Journal of basic microbiology 39 , 11-15.http://dx.doi.org/10.1002/(SICI)1521-4028(199903)39:1<11::AIDJOBM11>3.0.CO;2-8

DAMASO, M. C. T., PASSIANOTO, M. A., FREITAS, S. C. D., FREIRE, D. M. G., LAGO, R. C. A., COURI, S. 2008. Utilization of agroindustrial residues for lipase production by solid-state fermentation. Brazilian Journal of Microbiology, 39, 676-81.http://dx.doi.org/10.1590/S1517-83822008000400015 DAYANANDAN, A., KANAGARAJ J., SOUNDERRAJ, L., GOVINDARAJU, R., SUSEELA RAJKUMAR G. 2003. Application of an alkaline protease in leather processing: an ecofriendly approach. Journal of Cleaner Production, 11(5), 533-536.http://dx.doi:10.1016/S0959-6526(02)00056-2

DELEPELAIRE, P. 2004. Type I secretion in gram-negative bacteria. Biochimica et Biophysica Acta (BBA)-Molecular Cell Research, 1694, 149-61.http://dx.doi.org/10.1016/j.bbamcr.2004.05.001

DENG LI, WANG XIAOJING, NIE KAILI, WANG FANG, LIU JUNFENG, $e t$ al.. 2011. Synthesis of wax esters by lipase-catalyzed esterification with immobilized lipase from Candida sp. 99-125. Chinese Journal of Chemical Engineering, 19(6), 978-982.http://dx.doi.org/10.1016/S1004-9541(11)60080-3

DHARMSTHITI, S., LUCHAI, S. 1999. Production, purification and characterization of thermophilic lipase from Bacillus sp. THL027. FEMS microbiology letters, $179, \quad 241-46 . h t t p: / / d x . d o i . o r g / 210.1111 / j .1574-$ 6968.1999.tb08734.x

DHEEMAN, D. S. 2011. Microbial lipases of potential in biocatalysis: screening, purification, molecular cloning and heterologous expression of actinomycete lipases in Escherichia coli. Dublin Institute of Technology.

DIZGE, N., AYDINER, C., IMER, D. Y., BAYRAMOGLU, M., TANRISEVEN, A., KESKINLER, B. 2009. Biodiesel production from sunflower, soybean, and waste cooking oils by transesterification using lipase immobilized onto a novel microporous polymer. Bioresource Technology ,100, 1983-91.http://dx.doi.org/10.1016/j.biortech.2008.10.008

DUONG, F., SOSCIA, C., LAZDUNSKI, A., MURGIER, M. 1994. The Pseudomonas fluorescens lipase has a C-terminal secretion signal and is secreted by a three-component bacterial ABC-exporter system. Molecular microbiology, 11, 1117-26.http://dx.doi.org/10.1111/j.1365-2958.1994.tb00388.x

EL KHATTABI, M., VAN GELDER, P., BITTER, W., TOMMASSEN, J. 2003. Role of the calcium ion and the disulfide bond in the Burkholderia glumae lipase. Journal of Molecular Catalysis B: Enzymatic, 22 329-38.http://dx.doi.org/10.1016/S1381-1177(03)00047-X

ERTUĞRUL, S., DÖNMEZ, G., TAKAÇ, S. 2007. Isolation of lipase producing Bacillus sp. from olive mill wastewater and improving its enzyme activity Journal of Hazardous Materials, 720-24.http://dx.doi.org/10.1016/j.jhazmat.2007.04.034

FANG, Y., LU, Z., LV, F., BIE, X., LIU, S., et al.. 2006. A newly isolated organic solvent tolerant Staphylococcus saprophyticus M36 produced organic solvent-stable lipase. Current microbiology, 53 , 510-15.http://dx.doi.org/10.1007/s00284-006-0260-x

FARRELL, R. L., HATA, K., WALL, M. B. 1997. Solving pitch problems in pulp and paper processes by the use of enzymes or fungi. Biotechnology in the Pulp and Paper Industry, pp. 197-212. Springer.http://dx.doi.org/10.1007/BFb0102075

FICKERS, P., ONGENA, M., DESTAIN, J., WEEKERS, F., THONART, P. 2006. Production and down-stream processing of an extracellular lipase from the yeast Yarrowia lipolytica. Enzyme and microbial technology, 38 , 756-59.http://dx.doi.org/10.1016/j.enzmictec.2005.08.005

FUKUDA, S., HAYASHI, S., OCHIAI, H., IIIZUMI, T., NAKAMURA, K. 1990. Improvers for deinking of wastepaper. Japanese Patent 2: 229,90

GANDHI, N. N. 1997. Applications of lipase. Journal of the American Oil Chemists' Society, 74, 621-34.http://dx.doi.org/10.1007/s11746-997-0194-x

GATFIELD, I. L., HILMER, J.-M., BERTRAM, H.-J. 2001. The use of natural fatty acids for the biotechnological production of natural flavour compounds: application to ethyl trans-2, cis-4-decadienoate. CHIMIA International Journal for Chemistry, 55, 397-400.

GODFREY, T., REICHELT, J. 1982. Industrial enzymology: the application of enzymes in industry. Nature Press,New York, USA

GOHEL, H., GHOSH, S., BRAGAZNA, V. 2013. Production, purification and immobilization of extracellular lipases from thermophilic Bacillus subtilis XRF11 and Bacillus licheniformis XRF12 for production of alkyl esters.

GOMBERT, A. K., PINTO, A. L., CASTILHO, L. R., FREIRE, D. M. 1999 Lipase production by Penicillium restrictum in solid-state fermentation using babassu oil cake as substrate. Process Biochemistry, 35 , 85-90.http://dx.doi.org/10.1016/S0032-9592(99)00036-9 
GUPTA, N., SAHAI, V., GUPTA, R. 2007. Alkaline lipase from a novel strain Burkholderia multivorans: Statistical medium optimization and production in a bioreactor.

Process Biochemistry,

42, 518-26.http://dx.doi.org/10.1016/j.procbio.2006.10.006

GUTARRA, M. L., GODOY, M. G., MAUGERI, F., RODRIGUES, M. I., FREIRE, D. M., CASTILHO, L. R. 2009. Production of an acidic and thermostable lipase of the mesophilic fungus Penicillium simplicissimum by solid-state fermentation. Bioresource technology

5249-54.http://dx.doi.org/10.1016/j.biortech.2008.08.050

HABA, E., BRESCO, O., FERRER, C., MARQUES, A., BUSQUETS, M., MANRESA, A. 2000. Isolation of lipase-secreting bacteria by deploying used frying oil as selective substrate. Enzyme and microbial technology, 26, 40-44.http://dx.doi.org/10.1016/S0141-0229(99)00125-8

HAMID, N. S. A., ZEN, H. B., TEIN, O. B., HALIFAH, Y. M., SAARI, N., BAKAR, F. A. 2003. Screening and identification of extracellular lipaseproducing thermophilic bacteria from a Malaysian hot spring. World Journal of $\begin{array}{llll}\text { Microbiology and Biotechnology, } & 19, & 961-68 .\end{array}$ http://dx.doi.org/10.1023/B:WIBI.0000007330.84569.39

HASAN, F., SHAH, A. A., HAMEED, A. 2006. Industrial applications of microbial lipases. Enzyme and Microbial Technology, 39 , 235-51.http://dx.doi.org/10.1016/j.enzmictec.2005.10.016

HIOL, A., JONZO, M. D., DRUET, D., COMEAU, L. 1999. Production, purification and characterization of an extracellular lipase from Mucor hiemalis $f$ hiemalis. Enzyme and Microbial Technology, 25, 80-87.http://dx.doi.org/10.1016/S0141-0229(99)00009-5

HIOL, A., JONZO, M. D., RUGANI, N., DRUET, D., SARDA, L., COMEAU, L. C. 2000. Purification and characterization of an extracellular lipase from a thermophilic Rhizopus oryzae strain isolated from palm fruit. Enzyme and microbial technology, 26, 421-30. http://dx.doi.org/10.1016/S0141 0229(99)00173-8

HUN, C. J., RAHMAN, R. N. Z. A., SALLEH, A. B., BASRI, M. 2003. A newly isolated organic solvent tolerant Bacillus sphaericus 205y producing organic solvent-stable lipase. Biochemical Engineering Journal, 15, 147-51.http://dx.doi.org/10.1016/S1369-703X(02)00185-7

JAEGER, K.-E., EGGERT, T. 2002. Lipases for biotechnology. Current opinion in Biotechnology, 13, 390-97.http://dx.doi.org/10.1016/S0958-1669(02)00341-5 JAEGER, K.-E., REETZ, M. T. 1998. Microbial lipases form versatile tools for biotechnology. Trends in biotechnology, 396-403.http://dx.doi.org/10.1016/S0167-7799(98)01195-0

JAEGER, K., DIJKSTRA, B., REETZ, M. 1999. Bacterial biocatalysts: molecular biology, three-dimensional structures, and biotechnological applications of lipases. Annual Reviews in Microbiology, 53, 315-51.

JOSEPH, B., RAMTEKE, P. W. 2013. Extracellular solvent stable cold-active lipase from psychrotrophic Bacillus sphaericus MTCC 7526: partial purification and characterization. Annals of Microbiology, 63 , 363-70.http://dx.doi.org/10.1007/s13213-012-0483-y

JOSEPH, B., SHRIVASTAVA, N., RAMTEKE, P. W. 2012. Extracellular coldactive lipase of Microbacterium luteolum isolated from Gangotri glacier, western Himalaya: Isolation, partial purification and characterization. Journal of Genetic Engineering and Biotechnology,

137-44.http://dx.doi.org/10.1016/j.jgeb.2012.02.001

KAHVECI, D., FALKEBORG, M., GREGERSEN, S., XU, X. 2010. Upgrading of farmed salmon oil through lipase-catalyzed hydrolysis. Open Biotechnology Journal, 4, 47-55.

KAHVECI, D., XU, X. 2011. Repeated hydrolysis process is effective for enrichment of omega 3 polyunsaturated fatty acids in salmon oil by Candida rugosa lipase. Food Chemistry

1552-58.http://dx.doi.org/10.1016/i.foodchem.2011.05.142

KAIEDA, M., SAMUKAWA, T., KONDO, A., FUKUDA, H. 2001. Effect of methanol and water contents on production of biodiesel fuel from plant oil catalyzed by various lipases in a solvent-free system. Journal of Bioscience and Bioengineering, 91, 12-15.http://dx.doi.org/10.1016/S1389-1723(01)80103-1

KAMINI, N., FUJII, T., KUROSU, T., IEFUJI, H. 2000. Production, purification and characterization of an extracellular lipase from the yeast, Cryptococcus sp. S2. Process Biochemistry, 36, 317-24. http://dx.doi.org/10.1016/S0032 9592(00)00228-4

KAMINI, N., MALA, J., PUVANAKRISHNAN, R. 1998. Lipase production from Aspergillus niger by solid-state fermentation using gingelly oil cake. Process Biochemistry, 33, 505-11. http://dx.doi.org/10.1016/S00329592(98)00005-3

KANLAYAKRIT, W., BOONPAN, A. 2007. Screening of halophilic lipaseproducing bacteria and characterization of enzyme for fish sauce quality improvement. Kasetsart Journal (Natural Science), 41, 576-85.

KASHMIRI, M. A., ADNAN, A., BUTT, B. W. 2006. Production, purification and partial characterization of lipase from Trichoderma viride. African Journal of Biotechnology, 5

KHALIL, A. 2013. Isolation and characterization of three thermophilic bacterial strains (lipase, cellulose and amylase producers) from hot springs in Saudi Arabia. African Journal of Biotechnology, 10, 8834-39.
KIRK, O., BORCHERT, T. V., FUGLSANG, C. C. 2002. Industrial enzyme applications. Current opinion in biotechnology, 13 , 345-51.http://dx.doi.org/10.1016/S0958-1669(02)00328-2

KUMAR, S., KIKON, K., UPADHYAY, A., KANWAR, S. S., GUPTA, R. 2005. Production, purification, and characterization of lipase from thermophilic and alkaliphilic Bacillus coagulans BTS-3. Protein Expression and Purification, 41, 38-44. http://dx.doi.org/10.1016/j.pep.2004.12.010

LERIN, L. A., RICHETTI, A., DALLAGO, R., TREICHEL, H., MAZUTTI, M A., et al. 2012. Enzymatic synthesis of ascorbyl palmitate in organic solvents: Process optimization and kinetic evaluation. Food and Bioprocess Technology, 5 , 1068-76.http://dx.doi.org/10.1007/s11947-010-0398-1

LI, S., YANG, X., YANG, S., ZHU, M., WANG, X. 2012. Technology prospecting on enzymes: Application, marketing and engineering. Computational

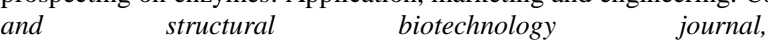

1-11.http://dx.doi.org/10.5936/csbj.201209017

LIU, K., ZHAO, G., HE, B., CHEN, L., HUANG, L. 2012a. Immobilization of pectinase and lipase on macroporous resin coated with chitosan for treatment of whitewater from papermaking. Bioresource technology, 123 , 616-19.http://dx.doi.org/10.1016/j.biortech.2012.07.074

LIU, T. Z., WANG, D. F., ZHAO, H. Y., ZHENG, K. Y. 2012b. Stickies treatments of recycled fiber pulping wastewater by lipases. Advanced Materials Research, 534 ,

$225-29$

http://dx.doi.org/10.4028/www.scientific.net/AMR.534.225

MAHADIK, N. D., PUNTAMBEKAR, U. S., BASTAWDE, K. B., KHIRE, J. M., GOKHALE, D. V. 2002. Production of acidic lipase by Aspergillus niger in solid state fermentation. Process Biochemistry, 38 715-21.http://dx.doi.org/10.1016/S0032-9592(02)00194-2

MARKOSSIAN, S., BECKER, P., MÄRKL, H., ANTRANIKIAN, G. 2000. Isolation and characterization of lipid-degrading Bacillus thermoleovorans IHI91 from an Icelandic hot spring Extremophiles 4 365-71.http://dx.doi.org/10.1007/s007920070006

MASE, T., ASANO, K., IKEDA, Y., KATO, Y., ESAKI, H., ISSHIKI, S. 2013. Characterization and application of lipase 39-A from Cryptococcus flavescens for Cheese flavoring. Food Science and Technology Research, 19 89-95.http://dx.doi.org/10.3136/fstr.19.89

MATSUMAE, H., FURUI, M., SHIBATANI, T. 1993. Lipase-catalyzed asymmetric hydrolysis of 3-phenylglycidic acid ester, the key intermediate in the synthesis of diltiazem hydrochloride. Journal of fermentation and bioengineering, 75, 93-98. http://dx.doi.org/10.1016/0922-338X(93)90216-U MATSUMIYA, Y., WAKITA, D., KIMURA, A., SANPA, S., KUBO, M. 2007. Isolation and characterization of a lipid-degrading bacterium and its application to lipid-containing wastewater treatment. Journal of bioscience and bioengineering, 103, 325-30. http://dx.doi.org/10.1263/jbb.103.325

MAUGARD, T., ENAUD, E., SAYETTE, A. D. L., CHOISY, P., LEGOY, M. D. 2002. $\beta$-Glucosidase-catalyzed hydrolysis of Indican from leaves of Polygonum tinctorium. Biotechnology progress,

1104-08.http://dx.doi.org/10.1021/bp025540

MAUGARD, T., LEGOY, M. D. 2000. Enzymatic synthesis of derivatives of vitamin A in organic media. Journal of Molecular Catalysis B: Enzymatic, 8 , 275-80. http://dx.doi.org/10.1016/S1381-1177(99)00078-8

MAUGARD, T., TUDELLA, J., LEGOY, M. D. 2000. Study of vitamin ester synthesis by lipasecatalyzed tran-sesterification in organic media. Biotechnology progress, 16, 358-62. http://dx.doi.org/10.1021/bp000034a

MENZI, R. 1970. METHOD OF MAKING DRIED PASTA HAVING A PROTEIN NETWORK THAT WITHSTANDS COOKING. U.S. Patent No 3,520,702. 14 Jul. 1970

MESSIAS, J. M., DA COSTA, B. Z., DE LIMA, V. M., DEKKER, R. F. REZENDE, M. I., et al.. 2009. Screening Botryosphaeria species for lipases: Production of lipase by Botryosphaeria ribis EC-01 grown on soybean oil and other carbon sources. Enzyme and Microbial Technology, 45, 426-31.http://dx.doi.org/10.1016/j.enzmictec.2009.08.013

MOBARAK-QAMSARI, E., KASRA-KERMANSHAHI, R., MOOSAVINEJAD, Z. 2011. Isolation and identification of a novel, lipase-producing bacterium, Pseudomnas aeruginosa KM110. Iranian journal of microbiology, 3 , 92.

MODI, M. K., REDDY, J., RAO, B., PRASAD, R. 2007. Lipase-mediated conversion of vegetable oils into biodiesel using ethyl acetate as acyl acceptor Bioresource Technology, 1260-64. http://dx.doi.org/10.1016/j.biortech.2006.05.006

MOHAMED, I. O. 2012. Lipase-catalyzed synthesis of cocoa butter equivalen from palm olein and saturated fatty acid distillate from palm oil physical refinery. Applied biochemistry and biotechnology, 168, 1405-15.http://dx.doi.org/10.1007/s12010-012-9866-6

MOHAMMED, S., TE'O, J., NEVALAINEN, H. 2013. A gene encoding a new cold-active lipase from an Antarctic isolate of Penicillium expansum. Current genetics, 59, 129-37. http://dx.doi.org/10.1007/s00294-013-0394-x

MORENO-PEREZ, S., FILICE, M., GUISAN, J. M., FERNANDEZ-LORENTE, G. 2013. Synthesis of ascorbyl oleate by trans-esterification of olive oil with ascorbic acid in polar organic media catalyzed by immobilized lipases. Chemistry 
$\begin{array}{llll}\text { and physics } & \text { of } & \text { lipids, } & 174,\end{array}$ http://dx.doi.org/10.1016/j.chemphyslip.2013.06.003

NAJJAR, A., ROBERT, S., GUÉRIN, C., VIOLET-ASTHER, M., CARRIÈRE, F. 2011. Quantitative study of lipase secretion, extracellular lipolysis, and lipid storage in the yeast Yarrowia lipolytica grown in the presence of olive oil: analogies with lipolysis in humans. Applied microbiology and biotechnology, 89, 1947-62. http://dx.doi.org/10.1007/s00253-010-2993-5

NERURKAR, M., JOSHI, M., PARITI, S., ADIVAREKAR, R. 2013. Application of lipase from marine bacteria Bacillus sonorensis as an additive in detergent formulation. Journal of Surfactants and Detergents, 16 , 435-43.http://dx.doi.org/10.1007/s11743-012-1434-0

NOUREDDINI, H., GAO, X., PHILKANA, R. 2005. Immobilized Pseudomonas cepacia lipase for biodiesel fuel production from soybean oil. Bioresource Technology, 96, 769-77. http://dx.doi.org/10.1016/j.biortech.2004.05.029

OKADA, T., MORRISSEY, M. T. 2007. Production of $\mathrm{n}-3$ polyunsaturated fatty acid concentrate from sardine oil by lipase-catalyzed hydrolysis. Food chemistry, 103, 1411-19. http://dx.doi.org/10.1016/j.foodchem.2006.10.057

OMAR, K. A., GOUNGA, M. E., LIU, R., MLYUKA, E., WANG, X. 2015 Effects of microbial lipases on hydrolyzed milk fat at different time intervals in flavour development and oxidative stability. Journal of Food Science and Technology, 1-12. http://dx.doi.org/10.1007/s13197-015-2158-8

PANDEY, A., BENJAMIN, S., SOCCOL, C. R., NIGAM, P., KRIEGER, N., SOCCOL, V. T. 1999. The realm of microbial lipases in biotechnology. Biotechnology and applied biochemistry,

119-31.http://dx.doi.org/10.1111/j.1470-8744.1999.tb00541.x

PARK, S.-Y., KIM, J.-Y., BAE, J.-H., HOU, C. T., KIM, H.-R. 2013 Optimization of culture conditions for production of a novel cold-active lipase from Pichia lynferdii NRRL Y-7723. Journal of agricultural and food chemistry, 61, 882-86.http://dx.doi.org/10.1021/jf304919y

PLEISS, J., FISCHER, M., SCHMID, R. D. 1998. Anatomy of lipase binding sites: the scissile fatty acid binding site. Chemistry and physics of lipids, 93 , 67-80.http://dx.doi.org/10.1016/S0009-3084(98)00030-9

PRAZERES, J. N. D., CRUZ, J. A. B., PASTORE, G. M. 2006. Characterization of alkaline lipase from Fusarium oxysporum and the effect of different surfactants and detergents on the enzyme activity. Brazilian Journal of Microbiology, 37, 505-09.http://dx.doi.org/10.1590/S1517-83822006000400019 PRIJI, P., UNNI, K., SAJITH, S., BINOD, P., BENJAMIN, S. 2014. Production, optimization and partial purification of lipase from Pseudomonas sp. strain BUP6, a novel rumen bacterium characterized from Malabari goat Biotechnology and applied biochemistry ,62(1), 71-78. http://dx.doi.org/10.1002/bab.1237

RATHI, P., SAXENA, R., GUPTA, R. 2001. A novel alkaline lipase from Burkholderia cepacia for detergent formulation. Process Biochemistry, 37, 187-92.http://dx.doi.org/10.1016/S0032-9592(01)00200-X

REYES-DUARTE, D., LOPEZ-CORTES, N., TORRES, P., COMELLES, F. PARRA, J., et al.. 2011. Synthesis and properties of ascorbyl esters catalyzed by lipozyme TL IM using triglycerides as acyl donors. Journal of the American Oil Chemists' Society, 88, 57-64. http://dx.doi.org/10.1007/s11746-010-1643-5

RIFAAT, H. M., EL-MAHALAWY, A. A., EL-MENOFY, H. A., DONIA, S. A. 2010. Production, optimization and partial purification of lipase from Fusarium oxysporum. Journal of applied sciences in environmental sanitation, 5, 39-53. RODRIGUEZ, J., MATEOS, J., NUNGARAY, J., GONZÁLEZ, V., BHAGNAGAR, T., et al.. 2006. Improving lipase production by nutrient source modification using Rhizopus homothallicus cultured in solid state fermentation. Process Biochemistry, 41, 2264-69. http://dx.doi.org/10.1016/j.procbio.2006.05.017

ROSENAU, F., JAEGER, K. E. 2000. Bacterial lipases from Pseudomonas: regulation of gene expression and mechanisms of secretion. Biochimie, 82(11), 1023-1032.http://dx.doi:10.1016/S0300-9084(00)01182-2

ROYON, D., DAZ, M., ELLENRIEDER, G., LOCATELLI, S. 2007. Enzymatic production of biodiesel from cotton seed oil using t-butanol as a solvent Bioresource Technology, 68, 648-53. http://dx.doi.org/10.1016/j.biortech.2006.02.021

SÁNCHEZ, M., PRIM, N., RÁNDEZ-GIL, F., PASTOR, F., DIAZ, P. 2002. Engineering of baker's yeasts, E. coli and Bacillus hosts for the production of Bacillus subtilis lipase A. Biotechnology and bioengineering, 78, 339-45.http://dx.doi.org/10.1002/bit.10201

SARAN, S., MAHAJAN, R. V., KAUSHIK, R., ISAR, J., SAXENA, R. K. (2013). Enzyme mediated beam house operations of leather industry: a needed step towards greener technology. Journal of Cleaner Production, 54, 315322.http://dx.doi:10.1016/j.jclepro.2013.04.017

SATHISH YADAV, K., ADSUL, M., BASTAWDE, K., JADHAV, D. THULASIRAM, H., GOKHALE, D. 2011. Differential induction, purification and characterization of cold active lipase from Yarrowia lipolytica NCIM 3639 Bioresource technology, $102, \quad 10663-70$. http://dx.doi.org/10.1016/j.biortech.2011.09.013

SCHMID, R. D., VERGER, R. 1998. Lipases: interfacial enzymes with attractive applications. Angewandte Chemie International Edition, 37,1608-33.http://dx.doi.org/10.1002/(SICI)1521-

3773(19980703)37:12<1608::AID-ANIE1608>3.0.CO;2-V
SHARMA, R., SONI, S., VOHRA, R., GUPTA, L., GUPTA, J. 2002 Purification and characterisation of a thermostable alkaline lipase from a new thermophilic Bacillus sp. RSJ-1. Process Biochemistry, 37 , 1075-84.http://dx.doi.org/10.1016/S0032-9592(01)00316-8

SHUKLA, P., GUPTA, K. 2007. Ecological screening for lipolytic molds and process optimization for lipase production from Rhizopus oryzae KG-5. Journal of Applied Sciences in Environmental Sanitation, 2, 35-42.

SINCHAIKUL, S., SOOKKHEO, B., PHUTRAKUL, S., PAN, F.-M., CHEN, S.-T. 2001. Optimization of a thermostable lipase from Bacillus stearothermophilus P1: overexpression, purification, and characterization. Protein expression and purification, 22, 388-98. http://dx.doi.org/10.1006/prep.2001.1456

SØE, J. B., POULSEN, C. H., RASMUSSEN, P., MADRID, S. M., ZARGAHI, M. R. 2005. Method for preparing flour doughs and products made from such doughs using lipase. U.S. Patent No. 6,852,346. 8 Feb. 2005.

SUN, J., JING, K., LU, Y. 2013. High regioselective acetylation of vitamin A precursors using lipase B from Candida antarctica in organic media. African Journal of Biotechnology, 10, 11990-97.

TAN, T., ZHANG, M., WANG, B., YING, C., DENG, L. 2003. Screening of high lipase producing Candida sp. and production of lipase by fermentation. Process Biochemistry, 39, 459-65. http://dx.doi.org/10.1016/S00329592(03)00091-8

TAN, T., ZHANG, M., XU, J., ZHANG, J. 2004. Optimization of culture conditions and properties of lipase from Penicillium camembertii Thom PG-3. Process Biochemistry, 39, 1495-502. http://dx.doi.org/10.1016/S0032 9592(03)00296-6

VERMA, N., THAKUR, S., BHATT, A. 2012. Microbial Lipases: Industrial applications and properties (A Review). International Research Journal of Biological Sciences, 1, 88-92.

WANG, Q., HOU, Y., DING, Y., YAN, P. 2012. Purification and biochemical characterization of a cold-active lipase from Antarctic sea ice bacteria Pseudoalteromonas sp. $\quad \mathrm{NJ} \quad 70 . \quad$ Molecular biology reports, 39, 9233-38.http://dx.doi.org/10.1007/s11033-012-1796-4

XING, C., YOU-GUANG, P., CHEN-XI, Z., ZHI-LIN, R., MING-XING, J., et al.. 2013. Screening of thermophilic neutral lipase-producing Pseudomonas sp. $\mathrm{ZBC} 1$ and improving its enzymatic activity. African Journal of Biotechnology, 12, 949-57.

YANG, F., WEBER, T. W., GAINER, J. L., CARTA, G. 1997. Synthesis of lovastatin with immobilized Candida rugosa lipase in organic solvents: effects of reaction conditions on initial rates. Biotechnology and bioengineering, 56, 671-80. http://dx.doi.org/10.1002/(SICI)1097-0290(19971220)56:6<671::AIDBIT10>3.0.CO;2-B

YANG, J.-G., WANG, Y.-H., YANG, B., MAINDA, G., GUO, Y. 2006 Degumming of vegetable oil by a new microbial lipase. Food Technology and Biotechnology, 44, 101.

YILMAZ, G., AYAR, A., AKIN, N. 2005. The effect of microbial lipase on the lipolysis during the ripening of Tulum cheese. Journal of food engineering, 69 , 269-74. http://dx.doi.org/10.1016/j.jfoodeng.2004.08.017

YU, D., MARGESIN, R. 2014. Partial characterization of a crude cold-active lipase from Rhodococcus cercidiphylli BZ22. Folia microbiologica, 17.http://dx.doi.org/10.1007/s12223-014-0318-2

ZHU, B., PANEK, J. S. 2001. Methodology based on chiral silanes in the synthesis of polypropionate-derived natural products - total synthesis of epothilone A. European Journal of Organic Chemistry, 2001, 1701-14. http://dx.doi.org/10.1002/1099-0690(200105)2001:9<1701::AID-

EJOC1701>3.0.CO;2-\#

ZOUAOUI, B., BOUZIANE, A. 2011. Isolation, Optimisation and purification of lipase production by Pseudomonas aeruginosa. Journal of Biotechnology and Biomaterial, 1, 2. http://dx.doi.org/10.4172/2155-952X.1000120 